\title{
Inhaled ceftazidime and amikacin versus inhaled colistin in the treatment of gram negative ventilator associated pneumonia
}

\author{
YS Nassar", M Ibrahim, AG Salman, TS Elgohary \\ From ESICM LIVES 2015 \\ Berlin, Germany. 3-7 October 2015
}

\section{Introduction}

Aerosol antibiotics administration offers the theoretical advantages of achieving high drug concentrations at the infection site and low systemic absorption.

\section{Objectives}

Comparing the microbiological outcome of inhaled ceftazidime amikacin versus inhaled colistin as adjunctives to conventional iv antibiotics in treating gram negative VAP.

\section{Methods}

This prospective randomized controlled study was carried out on 60 mechanically ventilated patients with gram negative VAP.

Inclusion criteria: Adult mechanically ventilated patients diagnosed to have Gram negative VAP confirmed: Radiologically (new chest $\mathrm{x}$ - ray infiltrate).

- Microbiologically (positive culture from aspirate of endo- tracheal tube (ETT).

- Clinically (fever, leukocytosis and increased bronchial secretion). CPIS scoring $>6$.

Exclusion criteria: - Severe renal impairment,

The patients included in the study were equally randomized to enter one of 3 groups; group A, group B or group C.

- Group (A) 20 patients: nebulized ceftazidime (15 mg. $\mathrm{kg} .3 \mathrm{~h}$ ) plus nebulized amikacin $(25 \mathrm{mg} \cdot \mathrm{kg} \cdot \mathrm{d})$ in addition to conventional IV antibiotics.

- Group (B) 20 patients: nebulized Colistin (1million IU every $8 \mathrm{~h}$ ) in addition to

conventional IV antibiotics.

- Group (C) 20 patients: conventional IV antibiotics.

Cairo University, Cairo, Egypt

(C) 2015 Nassar et al.; This is an Open Access article distributed under the terms of the Creative Commons Attribution License (http:// creativecommons.org/licenses/by/4.0), which permits unrestricted use, distribution, and reproduction in any medium, provided the original work is properly cited.
In all groups $\mathrm{A}, \mathrm{B}$ and $\mathrm{C}$, treatment was continued for five days followed by ETT aspirate.

Interpretation of culture results:

Clearance: no growth. Resistance: persistent pathogen. Super infection: eradication of previous pathogen with developing of another pathogen. Resistance and super infection: persistent responsible pathogen with developing of another pathogen.

\section{Results}

The clearance of organism was $(75 \%$ vs. $80 \%$ vs. $50 \%)$, resistance was ( $5 \%$ vs. $5 \%$ vs. $20 \%)$, superinfection was $(0 \%$ vs. $10 \%$ vs. $15 \%$ ), while combined resistance and super infection was $(20 \%$ vs. $5 \%$ vs. $15 \%)$ in group A vs. B vs. C respectively.

Comparing group B vs. C: a significantly greater clearance $(80 \%$ vs. $50 \%$, p $\mathbf{0 . 0 4 7})$ while no significant difference regarding resistance (5\% vs. $20 \%$, p 0.151 ), superinfection ( $2 \%$ vs. $15 \%$, p 0.633$)$, combined resistance and super infection ( $5 \%$ vs. $15 \%$, p 0.292 ) in group B vs. C respectively.

Comparing group $\boldsymbol{A}$ vs. C: no significant difference in clearance ( $75 \%$ vs. $50 \%$, p 0.102$)$, resistance ( $5 \%$ vs. $20 \%$, p 0.151$)$, superinfection ( $0 \%$ vs. $15 \%$, p 0.072$)$, combined resistance and super infection (20\% vs. $15 \%, \mathrm{p} 0.667)$ in group A vs. C respectively.

Comparing group $\boldsymbol{A}$ vs. B: no significant difference in clearance ( $75 \%$ vs. $80 \%$, p 0.705$)$, resistance ( $5 \%$ vs. $5 \%$, p 1.0 ), superinfection ( $0 \%$ vs. $10 \%$, p 0.147$)$, combined resistance and super infection ( $20 \%$ vs. $5 \%$, p 0.151$)$ in group A vs. B respectively.

\section{Conclusions}

The addition of Inhaled Colistin showed a significantly better organism clearance after 5 days compared to 
inhaled Ceftazidime and Amikacin and compared to iv antibiotics without additional inhaled antibiotics, in treating gram negative VAP.

\section{Grant Acknowledgment}

Cairo University

Published: 1 October 2015

doi:10.1186/2197-425X-3-S1-A380

Cite this article as: Nassar et al:: Inhaled ceftazidime and amikacin versus inhaled colistin in the treatment of gram negative ventilator associated pneumonia. Intensive Care Medicine Experimental 2015

3(Suppl 1):A380.

Submit your manuscript to a SpringerOpen ${ }^{\odot}$ journal and benefit from:

- Convenient online submission

- Rigorous peer review

- Immediate publication on acceptance

- Open access: articles freely available online

- High visibility within the field

- Retaining the copyright to your article

Submit your next manuscript at $>$ springeropen.com 